\title{
Public support for lockdown policies
}

\author{
David Boto-García* \\ University of Oviedo, Spain
}

Received: 6 October 2020
Revised: 8 December 2020
Accepted: 14 February 2021

\begin{abstract}
Due to the outbreak of the COVID-19 disease, many countries in the world have been forced to impose non-pharmaceutical policy interventions such as lockdowns to stop community transmission. Although justified by public health reasons, this constitutes a great deprivation of freedom. I investigate public support for the lockdown policy in Spain, one of the countries most affected by the pandemic and with the strictest lockdown in Europe. Based on survey data collected during the first weeks of April and May 2020, I analyse how public support for the lockdown relates to the number of confirmed cases in the province of residence, personal institutional trust and concern about the severity of coronavirus. I find that public approval of the lockdown significantly relates to the evolution of COVID cases, institutional trust, political ideology and personal economic situation.
\end{abstract}

Keywords: COVID-19; institutional trust; public support; lockdown; health policy JEL Classification Codes: I10; I18

\section{Introduction}

On March $15^{\text {th }}, 2020$ the Spanish Government declared the State of Alarm for 15 days and imposed a lockdown by which all people were required to remain at their homes except to purchase food or medicines. Schools and non-essential shops and businesses were closed. At the time of the announcement, the number of confirmed cases of COVID-19 in Spain was rapidly increasing, and the government was urged by experts to confine the population to stop the community propagation of the virus ${ }^{1}$. The lockdown was implemented in the whole territory, albeit some regions were not very hit by the pandemic at that moment ${ }^{2}$. Although initially expected to be for 15 days, the government deemed it necessary to extend the lockdown during almost two months. The health system in Spain was in serious risk of collapse, and the number

*Corresponding author. E-mail: botodavid@uniovi.es.

Citation: Boto-García, D. (2021) Public support for lockdown policies, Economics and Business Letters, 10(3), 299-309.

DOI: 10.17811/ebl.10.3.2021.299-309

\footnotetext{
1 The spread of viruses is strongly associated with social interactions and mobility. Measures that prevent interpersonal contacts are considered as a necessary tool to control the propagation of contagious diseases (Adda, 2016). See also Mitjà et al. (2020).

${ }^{2}$ Evidence presented in Amuedo-Dorantes et al. (2020) suggests that the early adoption of the lockdown in the least affected areas was effective in terms of lowering the fatality rates by 2.5 dealth per 100,000 inhabitants.
} 
of deaths and hospitalizations continued rising during some weeks. On March, $28^{\text {th }}, 2020$, all non-essential activities were banned, starting the strictest two-week period of the lockdown. Nevertheless, some restrictions started to be relaxed from the middle of April onwards.

The nationwide lockdown was imposed because of public health reasons. In his press conferences, the Spanish Prime Minister indicated several times that public health had priority over all other concerns. However, forcing people to remain at their homes during almost two months was a great collective effort that completely changed society's daily lives from one day to another. Some studies have shown that depression and anxiety significantly increased among the general Spanish population during the lockdown (González-Sanguino et al., 2020; RodríguezRey et al., 2020). In this context, public support and acceptance of the necessity of taking these extreme decisions is relevant to facilitate compliance with the measures proposed by experts, social cohesiveness and to avoid public order problems or conspiracy theories ${ }^{3}$.

I examine how public support for the strict lockdown imposed in Spain relates to the evolution in the number of confirmed COVID-19 cases in the province of residence, trust in the capacity of the government to manage the situation, and personal concern about the severity of the disease. I use representative survey data of the Spanish population on public opinions about the pandemic collected during the first weeks of April and May, when the population was under the lockdown. Our analysis also considers sociodemographic characteristics, indicators of religiosity and political ideology, a time trend and province fixed effects as control variables. I provide evidence that public sentiment towards confinement decisions is strongly associated with the epidemiological situation at the province of residence. I also find some heterogeneity in attitudes towards the lockdown based on political ideology, personal economic situation and education. Concern about the coronavirus and trust in the government are positively associated with the support for the measures adopted.

The study adds to a scarce but growing body of literature on public attitudes towards health policies after the COVID-19 pandemic. Using survey data from 58 countries at the onset of the COVID-19 crisis, Fetzer et al. (2020) report that most citizens consider their government's responses were insufficient, but that the announcement of a nationwide lockdown increased improved respondents' well-being. Wright et al. (2020) find that confidence in the government's capacity to tackle the pandemic is longitudinally related to higher compliance with COVID-19 guidelines in the UK. Similar results are reported in Guglielmi et al. (2020) for the Italian case. Using data for Europe and the U.S., Barrios et al. (2020) show that compliance with social distancing is more prevalent among those with a higher sense of civic duty. Bol et al. (2020) find that lockdowns have increased vote intentions for the party of the Prime Minister and trust in the government. Similarly, Sibley et al. (2020) show that after the outbreak of the pandemic people in New Zealand report higher trust in science, politicians and police. Using survey data for seven European countries, Sabat et al. (2020) document a north-south divide in people's approval of policies, with those in the south prioritising the economic consequences of the pandemic. Goolsbee and Syverson (2020) indicate that legal shutdown orders account for only a small share of the decline of economic activity in the USA, and that personal fear of infection was more important to reduce mobility than government-imposed restrictions. Interestingly, they show the drop in mobility is strongly linked to COVID-19 deaths in the county ${ }^{4}$

For the Spanish case, Amat et al. (2020) provide evidence that citizens shifted strongly towards preference for technocratic governance and strong leadership following the pandemic outbreak. They also show that people prefer a national as opposed to an international policy response to the health crisis and that they are willing to give up individual freedom to battle the virus propagation. This work contributes to this emerging literature by showing how support

\footnotetext{
${ }^{3}$ There is some evidence that disasters can act as democratizing devices (e.g. Brückner and Ciccone, 2011).

${ }^{4}$ A review of the early literature about political trust in the aftermath of COVID-19 pandemic can be found in Devine et al. (2020).
} 
for the lockdown correlates with the severity of the epidemiological situation at the province of residence, personal concern about COVID-19 and institutional trust net of other confounding factors.

\section{Data}

I use the April 2020 and May 2020 waves of the monthly Barometer conducted by the Spanish Centre for Sociological Research (CIS). This is a public organism in charge of collecting public opinion data for economic, sociological and demographic research. The CIS surveys a representative sample of the Spanish population over 18 to ascertain people's voting intentions, opinions about current affairs and main concerns. Personal and sociodemographic characteristics are also gathered.

The sampling was done in 1,416 municipalities pertaining to the 52 Spanish provinces. A total of 3,000 people participated in the April wave. The interviews took place by telephone between the $30^{\text {th }}$ of March and the $7^{\text {th }}$ of April. The fieldwork in the May wave was conducted between the $4^{\text {th }}$ and the $13^{\text {th }}$ of May and consists of 3,800 people. The database provides the date the survey was conducted. Figure 1 graphs the distribution of surveys collected per day ${ }^{5}$. Since participants are not the same, the dataset is a pool of cross-sectional units. After dropping some individuals with missing values in the variables of interest, the dataset comprises 6,242 valid observations.

In the two waves, respondents are asked their opinion about the strict lockdown policy implemented by the Spanish Government in middle March. Respondents can choose one of the following options: 1) Not necessary at all, 2) Little necessary, 3) Moderate, 4) Required but not essential, and 5) Highly necessary. Table 1 presents the distribution of the answers provided.

Figure 1. Number of collected surveys per day.

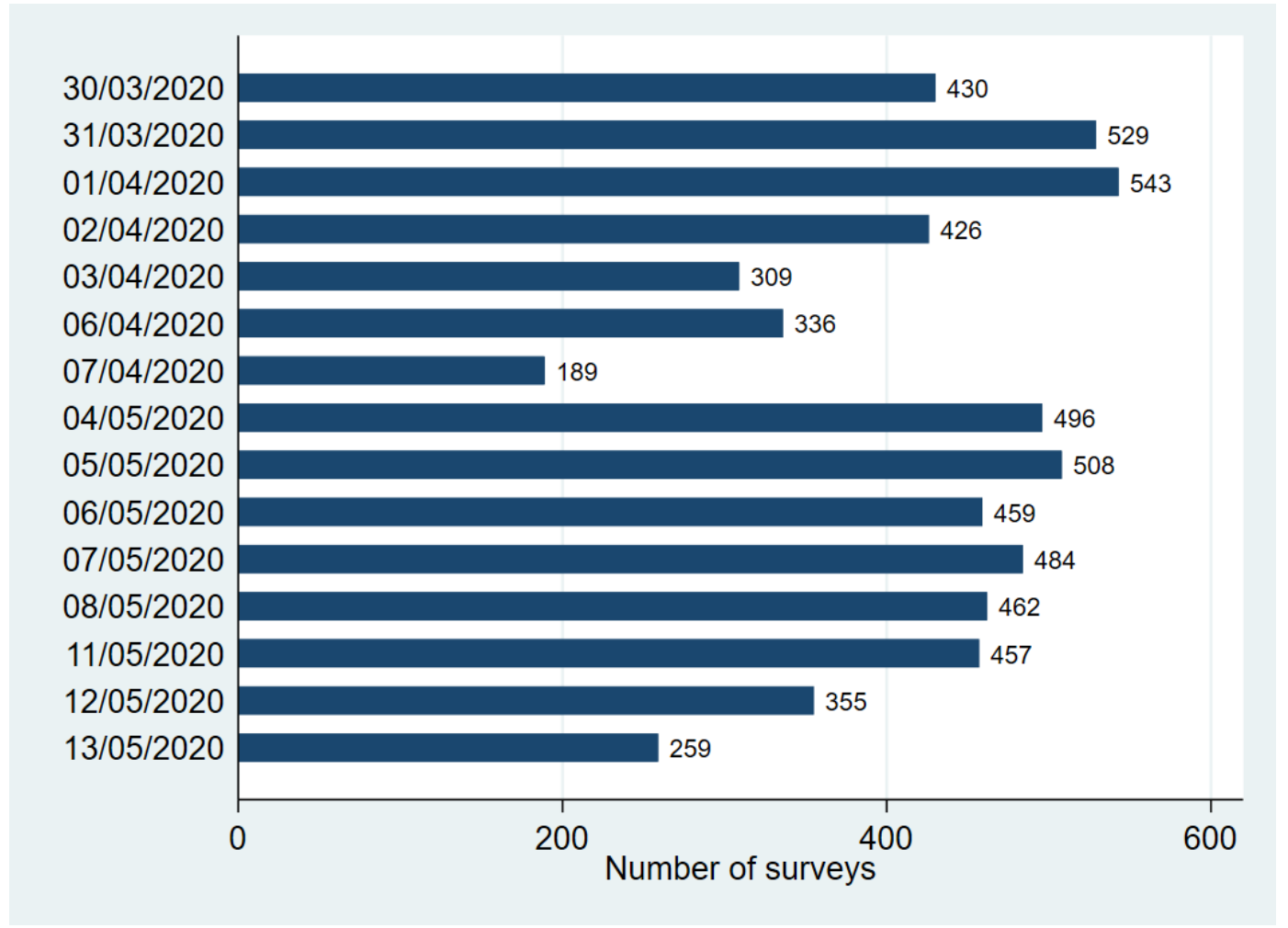

\footnotetext{
${ }^{5}$ Data is only collected during weekdays, and that is why there are no surveys for the $4^{\text {th }}$ and $5^{\text {th }}$ of March (weekend) and the $9^{\text {th }}$ and $10^{\text {th }}$ May (weekend).
} 
Table 1. Answers about the suitability of the lockdown policy.

\begin{tabular}{lrr}
\hline \hline \multicolumn{3}{l}{ Question: Concerning the actions taking by the govern- } \\
ment to battle COVID-19, how do you consider them? \\
Answer & $\mathbf{N}$ & $\mathbf{\%}$ \\
\hline Not necessary at all & 44 & 0.7 \\
Little necessary & 129 & 2.1 \\
Moderate & 17 & 0.3 \\
Required but not essential & 1,896 & 30.4 \\
Highly necessary & 4,156 & 66.5 \\
\hline \multicolumn{3}{l}{} \\
\hline \hline
\end{tabular}

Most respondents consider the lockdown decision to have been highly necessary (66.5\%). Interestingly, more than $30 \%$ consider the lockdown to be required but not essential. The remaining $3.1 \%$ seem to be against the confinement, but with different degree of opposition. This variable is denoted as lockdown support.

Public support for the lockdown decision might be affected by the epidemiological situation in respondents' province of residence. The lockdown was imposed for the whole country, even though some regions like Madrid or Catalonia were more affected than others. This might cause those in regions with fewer cases to be less supportive of the lockdown decision. To explore this, I collect daily data on confirmed COVID cases per province (through a positive PCR test). This data is retrieved from the National Epidemiological Surveillance Network (RENAVE) ${ }^{6}$. Each individual was matched with the number of COVID-19 cases in her province of residence i) the day before and ii) seven days before the survey took place ${ }^{7}$. This is because attitudes might not adjust instantaneously the epidemiological situation, but rather people react with some delay. In both cases, I specifically consider the total number of cases per 100.000 inhabitants to acknowledge population size differences across provinces (cases_lday and cases_lweek). In this way, I exploit the geographical and temporal variability in COVID-19 cases across respondents.

Survey participants are also asked to rate on a 5-point Likert scale (where 1=nothing at all and $5=a$ lot ) their degree of concern about the pandemic (denoted as COVID concern). In addition, they are required to indicate their trust in the capacity of the government to manage the pandemic situation (denoted as trust). This is also rated on a 5-point Likert scale (where $1=n o$ confidence and 5=much trust). Therefore, higher values of both scores mean higher concern about the pandemic and higher trust in the government.

To formally study the role of the epidemiological situation at the place of residence, concern about the pandemic, and institutional trust on the lockdown support, I propose the following regression model:

$$
\begin{aligned}
& \text { lockdown support } \\
& =f\left(\text { COVID cases, COVID cases }{ }^{2}, \text { COVID concern, trust, X, province FE, trend }\right) \\
& +\varepsilon
\end{aligned}
$$

where COVID cases $=\{$ cases_1day, cases_1week $\}$ is the indicator of confirmed cases in the province of residence in each case, trend is a time indicator to control for the evolution of the pandemic and $\varepsilon$ is a random error term.

\footnotetext{
${ }^{6}$ The data is available at https://cnecovid.isciii.es/covid19/

${ }^{7}$ I consider the province as the relevant geographical unit of analysis because the relaxation of some of the restrictions associated with the lockdown differed by province depending on its epidemiological situation.
} 
Table 2. Summary statistics.

\begin{tabular}{lrrrr}
\hline \hline Variables & Mean & SD & Min & Max \\
\hline lockdown support & 4.60 & 0.67 & 1 & 5 \\
cases_lday & 4.29 & 6.28 & 0 & 40.48 \\
cases_lweek & 6.83 & 9.37 & 0 & 72.48 \\
COVID concern & 4.53 & 0.64 & 1 & 5 \\
trust & 2.91 & 1.35 & 1 & 5 \\
female & 0.50 & 0.500 & 0 & 1 \\
age & 49.71 & 16.63 & 18 & 97 \\
no studies & 0.01 & 0.11 & 0 & 1 \\
primary education & 0.07 & 0.25 & 0 & 1 \\
secondary education & 0.25 & 0.43 & 0 & 1 \\
vocational training & 0.21 & 0.41 & 0 & 1 \\
university education & 0.44 & 0.49 & 0 & 1 \\
married & 0.56 & 0.49 & 0 & 1 \\
municipality size & 3.97 & 1.67 & 1 & 7 \\
employed & 0.53 & 0.49 & 0 & 1 \\
retired & 0.25 & 0.43 & 0 & 1 \\
unemployed & 0.12 & 0.33 & 0 & 1 \\
student & 0.05 & 0.22 & 0 & 1 \\
housewife & 0.03 & 0.17 & 0 & 1 \\
economic situation & 3.53 & 0.92 & 1 & 5 \\
high class & 0.12 & 0.32 & 0 & 1 \\
medium-high class & 0.45 & 0.49 & 0 & 1 \\
medium class & 0.23 & 0.42 & 0 & 1 \\
working class & 0.09 & 0.29 & 0 & 1 \\
poor class & 0.06 & 0.23 & 0 & 1 \\
political ideology & 4.64 & 2.06 & 1 & 10 \\
catholic & 0.17 & 0.38 & 0 & 1 \\
Observations & 6,242 & & & \\
\hline \hline
\end{tabular}

Notes: The variables cases_lday and cases_lweek refer to the confirmed cases per 100,000 inhabitants the day before and a week before the survey after a positive PCR test. The size of the municipality of residence comprises 7 categories: $=1$ for less than 2,000 inhabitants; $=2$ for between 2,000 and 10,000 inhabitants; $=3$ from 10,000 to 50,000 inhabitants; $=4$ from 50,000 to 100,000 inhabitants; $=5$ from 100,000 to 400,000 inhabitants; $=6$ from 400,000 to $1,000,000$ inhabitants; $=7$ for more than $1,000,000$ inhabitants. The economic situation is a 5-point indicator ( $1=$ 'Very bad'; $5=$ 'Very good') based on the answers to the question: How do you rate your current personal economic situation? The variables referring to social class are based on the answers to the question: What is the social class you consider belonging to?

The model specification includes province fixed effects to control for time-invariant characteristics at the province level such as health assistance capacity, the degree population aging or climate conditions. I also consider the square of the number of COVID-19 cases to explore whether the relationship between the epidemiological situation in the area of residence and lockdown support is not linear.

The vector $X$ contains the following individual characteristics as controls: gender, age (both in levels and in a squared form to allow for non-linearities), education level (vocational training and university studies, with primary or secondary education being the reference category), civil 
status (a dummy for being married), the size of the municipality of residence (in intervals), labour status (distinguishing among employed, retired and unemployed, being inactive people the reference category), personal economic situation, subjective social class, political ideology (a 11-Likert scale where 0 means "far left" and 10 means "far right"), and religiosity (a dummy for being active Catholic). Summary statistics of the variables used in the analysis are presented in Table 2.

\section{Results}

Table 3 presents the coefficients estimates from OLS regressions using the two alternative indicators for the epidemiological situation introduced before. Standard errors are clustered at the Autonomous Community level $(\mathrm{c}=17)$. This is because provinces belonging to the same region share the same government. As such, the analysis needs to control for this potential source of cross-sectional correlation across spatial units.

Before discussing the results, it is important to acknowledge that our estimates cannot be given a causal interpretation. The reason is that the dependent variable and some of the explanatory variables are self-reported so that there might share common unobservables. Moreover, I cannot rule out the possibility of reverse causality so that individuals who are more supportive of the non-pharmaceutical interventions compile more with restrictions and therefore are less likely to be infected. Because of this, the estimates are interpreted in terms of associations. Nevertheless, the regression analysis informs us about the linkages between public support and the number of cases net of other confounding factors.

There is a positive and significant association between the number of daily confirmed COVID-19 cases at the province of residence the day before (cases_lday) and support for the lockdown, although at a decreasing rate according to the squared term. The same pattern holds when the number of confirmed cases corresponding to one week ago (cases_lweek) are considered. This seems to suggest that people are more likely to support the lockdown in provinces with a large number of contagious cases, ceteris paribus.

Personal concern about the severity of the pandemic (COVID concern) is significantly correlated with a greater support towards the lockdown. The same applies to institutional trust (trust). Accordingly, a greater confidence in the capacity of the government to manage the situation is significantly associated with a higher support.

Lockdown support is found to be higher among females and high-educated people. Nonetheless, note that the magnitude of the effects is larger among those with vocational training than among university graduates. Concerning the role of age, the combined average marginal effect is around -0.004 and significant at $95 \%$ confidence level in the two model specifications, which indicates that elderly people are less likely to support the lockdown. Respondents in good economic conditions are more supportive, possibly because their income and well-being are less threatened by the confinement. Indeed, unemployed people seem to consider it less necessary. Interestingly, support for government actions is higher among respondents that locate themselves on the left side of the political ideology scale. This might be explained by the fact that the Spanish government is a coalition of two left-wing parties (PSOE and Unidas Podemos), so it makes sense the support for their decisions is greater among their voters. By contrast, I do not detect significant differences in sentiment towards the lockdown based on social class, the size of the municipality, religiosity or civil status.

I performed some robustness checks to our analysis. First, since the dependent variable is constructed as an ordered indicator, the two model specifications were re-estimated using an Ordered Probit regression. The estimates can be found in columns 1 and 2 in Appendix Table A1. The results remain qualitatively the same. Second, due to the left-skewed distribution of the dependent variable, I collapsed the first three responses (not necessary at all, little necessary 
Table 3. Coefficient estimates from linear regressions.

\begin{tabular}{|c|c|c|}
\hline $\begin{array}{l}\text { Dependent variable: } \\
\text { lockdown support }\end{array}$ & (1) & (2) \\
\hline cases_lday & $\begin{array}{r}0.0214 * * * \\
(0.0044)\end{array}$ & \\
\hline cases_1day square & $\begin{array}{r}-0.0008 * * * \\
(0.0002)\end{array}$ & \\
\hline cases_lweek & & $\begin{array}{r}0.0121 * * * \\
(0.0041)\end{array}$ \\
\hline cases_1week square & & $\begin{array}{r}-0.0002 * * * \\
(0.0001)\end{array}$ \\
\hline COVID concern & $\begin{array}{r}0.1386 * * * \\
\quad(0.0205)\end{array}$ & $\begin{array}{r}0.1391 * * * \\
(0.0206)\end{array}$ \\
\hline trust & $\begin{array}{r}0.1051 * * * \\
(0.0065)\end{array}$ & $\begin{array}{r}0.1048 * * * \\
(0.0065)\end{array}$ \\
\hline female & $\begin{array}{r}0.1085 * * * \\
(0.0191)\end{array}$ & $\begin{array}{r}0.1085 * * * \\
(0.0193)\end{array}$ \\
\hline age & $\begin{array}{c}0.0070^{*} \\
(0.0039)\end{array}$ & $\begin{array}{c}0.0070 * \\
(0.0038)\end{array}$ \\
\hline age square & $\begin{array}{r}-0.0001 * * \\
(0.0000)\end{array}$ & $\begin{array}{r}-0.0001 * * \\
(0.0000)\end{array}$ \\
\hline vocational training & $\begin{array}{r}0.0703 * * * \\
\quad(0.0237)\end{array}$ & $\begin{array}{r}0.0693 * * \\
(0.0241)\end{array}$ \\
\hline university education & $\begin{array}{r}0.0588 * * \\
(0.0214)\end{array}$ & $\begin{array}{r}0.0575^{* *} \\
(0.0214)\end{array}$ \\
\hline married & $\begin{array}{r}0.0089 \\
(0.0230)\end{array}$ & $\begin{array}{r}0.0090 \\
(0.0230)\end{array}$ \\
\hline municipality size & $\begin{array}{r}-0.0049 \\
(0.0040)\end{array}$ & $\begin{array}{r}-0.0053 \\
(0.0039)\end{array}$ \\
\hline employed & $\begin{array}{r}-0.0375 \\
(0.0259)\end{array}$ & $\begin{array}{r}-0.0381 \\
(0.0259)\end{array}$ \\
\hline retired & $\begin{array}{r}-0.0101 \\
(0.0384)\end{array}$ & $\begin{array}{r}-0.0102 \\
(0.0384)\end{array}$ \\
\hline unemployed & $\begin{array}{r}-0.0497 * \\
(0.0247)\end{array}$ & $\begin{array}{r}-0.0511 * * \\
(0.0241)\end{array}$ \\
\hline economic situation & $\begin{array}{r}0.0367 * * * \\
(0.0092)\end{array}$ & $\begin{array}{r}0.0363 * * * \\
(0.0090)\end{array}$ \\
\hline high class & $\begin{array}{r}0.0037 \\
(0.0365)\end{array}$ & $\begin{array}{r}0.0049 \\
(0.0364)\end{array}$ \\
\hline medium-high class & $\begin{array}{r}-0.0275 \\
(0.0194)\end{array}$ & $\begin{array}{r}-0.0277 \\
(0.0195)\end{array}$ \\
\hline medium class & $\begin{array}{r}0.0034 \\
(0.0210)\end{array}$ & $\begin{array}{r}0.0023 \\
(0.0212)\end{array}$ \\
\hline political ideology & $\begin{array}{r}-0.0156^{* * * *} \\
(0.0042)\end{array}$ & $\begin{array}{r}-0.0157 * * * \\
(0.0042)\end{array}$ \\
\hline catholic & $\begin{array}{r}0.0009 \\
(0.0306)\end{array}$ & $\begin{array}{r}0.0011 \\
(0.0313)\end{array}$ \\
\hline trend & $\begin{array}{r}-0.0077 * \\
(0.0040)\end{array}$ & $\begin{array}{r}-0.0061 * \\
(0.0054)\end{array}$ \\
\hline constant & $\begin{array}{r}3.4093 * * * \\
(0.1062)\end{array}$ & $\begin{array}{r}3.3861^{* * * *} \\
(0.1004)\end{array}$ \\
\hline Province FE & YES & YES \\
\hline Observations & 6,242 & 6,242 \\
\hline R-squared & 0.1133 & 0.1126 \\
\hline
\end{tabular}

Notes: Clustered standard errors at the Autonomous Community level in parentheses. $* * * \mathrm{p}<0.01, * * \mathrm{p}<0.05, * \mathrm{p}<0.1$. 
and moderate) into one category and run also an Ordered Probit with only three categories. The magnitude and significance of the effects are consistent (available upon request). Third, the provinces of Madrid and Barcelona have the greatest incidence in our sample, with an average number of total confirmed cases during the study period (in absolute terms) of 502 and 410, respectively. The national mean is 132.7 . To check whether their high values are affecting our results, I re-estimated the model without considering these two provinces (columns 3 and 4 in Appendix Table A1). The results remain unchanged. Finally, the model is re-estimated adopting a parsimonious specification in which all the control variables that are self-reported are omitted. The results are also consistent with the main analysis.

\section{Conclusion}

In the absence of medical interventions, policy makers have been forced to resort on non-medical interventions such as lockdown policies to prevent the spread of coronavirus disease. The effectiveness of the shutdown crucially relies on public attitudes towards this type of measures. Voluntary compliance with the lockdown and acceptance of its necessity to stop the virus is therefore of crucial importance for the appropriate enforcement of quarantines.

By merging survey data on public sentiment towards policy interventions collected in April and May with daily cases of COVID-19 at the province level, I have shown that lockdown support is associated with the epidemiologic situation at the place of residence. Individuals in provinces with a larger number of confirmed COVID-19 cases per 100,000 inhabitants perceive the limitations imposed by the confinement to be more necessary. Public approval is also related to concern about the severity of the disease and trust in the government. Therefore, policy makers must be aware of the great importance of the institutional trust they project on citizens for the successful sustainability of health policy interventions to battle the coronavirus. Importantly, support is found to be lower among the elderly, right-wing people and those with low education. This suggests that potential future lockdowns or containment measures need to be accompanied by appropriate communication messages that clearly explain and justify the reasons for the decisions made. This seems to be especially important for those segments that are more reluctant to shutdowns.

\section{References}

Adda, J. (2016). Economic activity and the spread of viral diseases: evidence from high frequency data, The Quarterly Journal of Economics, 131(2), 891-941.

Amuedo-Dorantes, C., Borra, C., Rivera-Garrido, N. \& Sevilla, A. (2020). Timing is everything when fighting a pandmeic: COVID-19 mortality in Spain, IZA Discussion Paper Series No. 13316.

Amat, F., Arenas, A., Faló-Gimeno, A. \& Muñoz, J. (2020). Pandemics meet democracy: Experimental evidence from the COVID-19 crisis in Spain, Working Paper.

Barrios, J.M. Benmelech, E., Hochberg, Y.V., Sapienza, P. \& Zingales, L. (2020). Civil capital and social distancing during the COVID-19 pandemic, Journal of Public Economics, 193, 104310, https://doi.org/10.1016/j.jpubeco.2020.104310.

Bol, D., Giani, M., Blais, A. \& Loewen, P.J. (2020). The effect of COVID-19 lockdowns on political support: some good news for democracy? European Journal of Political Research, forthcoming.

Brückner, M. \& Ciccone, A. (2011). Rain and the democratic window of opportunity, Econometrica, 79(3), 923-947.

Devine, D., Gaskell, J., Jennings, W. \& Stoker, G. (2020). Trust and the Coronavirus Pandemic: what are the consequences of and for trust? An early review of the literature, Political Studies Review, forthcoming. DOI: 10.1177/1478929920948684 
Fetzer, T., Witte, M., Hensel, L., Jachimowicz, J., Haushofer, J., Ivchenko, A., Caria, S., Reutskaja, E., Roth, C., Fiorin, S. \& Gómez, M. (2020). Perceptions of an insufficient government response at the onset of the COVID-19 pandemic are associated with lower mental well-being, PsyArxiv preprint available at https://doi. org/10.31234/osf. io/3kfmh

González-Sanguino, C., Ausín, B., Castellanos, M.A., Saiz, J., López-Gómez, A., Ugidos, C. \& Muñoz, M. (2020). Mental health consequences of the Coronavirus 2020 pandemic (COVID-19) in Spain. A longitudinal study, Frontiers in Psychiatry, forthcoming. https://doi.org/10.3389/fpsyg.2020.01540

Goolsbee, A. \& Syverson, C. (2020). Fear, lockdown and diversion: comparing drivers of pandemic economic decline 2020, Journal of Public Economics, 193, 104311, https://doi.org/10.1016/j.jpubeco.2020.104311

Guglielmi, S., Dotti Sani, G.M., Molteni, F., Biolcati, F., Chiesi, A.M., Ladini, R., Maraffi, M., Pedrazzani, A. \& Vezzoni, C. (2020). Public acceptability of containment measures during the COVID-19 pandemic in Italy: how institutional confidence and specific political support matter, International Journal of Sociology and Social Policy, 40(9/10), 1069-1085.

Mitjà, O., Arenas, À., Rodó, X., Tobias, A., Brew, J., \& Benlloch, J. M. (2020). Experts' request to the Spanish Government: move Spain towards complete lockdown, The Lancet, 395(10231), 1193-1194.

Rodríguez-Rey, R., Garrido-Hernansaiz, H. \& Collado, S. (2020). Psychological impact and associated factors during the initial stage of the Coronavirus (COVID-19) pandemic among the general population in Spain, Frontiers in Psychology, forthcoming. https://doi.org/10.3389/fpsyg.2020.01540

Sabat, I., Neuman-Böhme, S., Varghese, N.E., Barros, P.P., Brouwer, W., van Exel, J., Schreyögg, J. \& Stargardt, T. (2020). United but divided: policy responses and people's perceptions in the EU during the COVID-19 outbreak, Health Policy, forthcoming.

Sibley, C.G., Greaves, L.M., Satherley, N., Wilson, M.S., Overall, N.C., Lee, C.H., Milojev, P., Bulbulia, J., Osborne, D., Milfont, T.L., Houkamau, C.A. \& Houkamau, C.A. (2020). Effects of the COVID-19 pandemic and nationwide lockdown on trust, attitudes toward government, and well-being, American Psychologist, 75(5), 618-630.

Wright, L., Steptoe, A. and Fancourt, D. (2020). What predicts adherence to COVID-19 government guidelines? Longitudinal analyses of 51,000 UK adults, medRxiv preprint doi: https://doi.org/10.1101/2020.10.19.20215376 


\section{Appendix A - Coefficient estimates from robustness checks regressions}

Table A1. Coefficient estimates from robustness checks regressions.

\begin{tabular}{|c|c|c|c|c|}
\hline $\begin{array}{l}\text { Dependent } \\
\text { variable: } \\
\text { lockdown support }\end{array}$ & $\begin{array}{r}(1) \\
\text { Ordered } \\
\text { Probit }\end{array}$ & $\begin{array}{r}(2) \\
\text { Ordered } \\
\text { Probit }\end{array}$ & $\begin{array}{r}(3) \\
\text { OLS }\end{array}$ & $\begin{array}{r}(4) \\
\text { OLS }\end{array}$ \\
\hline cases_lday & $\begin{array}{r}0.0479 * * * \\
(0.0093)\end{array}$ & & $\begin{array}{r}0.0185 * * \\
(0.0068)\end{array}$ & \\
\hline cases_1day square & $\begin{array}{r}-0.0017 * * * \\
(0.0004)\end{array}$ & & $\begin{array}{r}-0.0007 * * * \\
(0.0002)\end{array}$ & \\
\hline cases_lweek & & $\begin{array}{r}0.0301 * * * \\
(0.0072)\end{array}$ & & $\begin{array}{r}0.0043 * * * \\
(0.0009)\end{array}$ \\
\hline $\begin{array}{l}\text { cases_lweek } \\
\text { square }\end{array}$ & & $-0.0006^{* * *}$ & & $-1.6 \mathrm{e}-05 * * *$ \\
\hline & & $(0.0001)$ & & $(0.0000)$ \\
\hline COVID concern & $\begin{array}{r}0.2716 * * * \\
\quad(0.0333)\end{array}$ & $\begin{array}{r}0.2731 * * * \\
\quad(0.0336)\end{array}$ & $\begin{array}{r}0.1310 * * * \\
(0.0211)\end{array}$ & $\begin{array}{r}0.1313 * * * \\
(0.0212)\end{array}$ \\
\hline trust & $\begin{array}{r}0.2082 * * * \\
\quad(0.0149)\end{array}$ & $\begin{array}{r}0.2075 * * * \\
\quad(0.0150)\end{array}$ & $\begin{array}{r}0.0992 * * * \\
\quad(0.0054)\end{array}$ & $\begin{array}{r}0.0993 * * * \\
(0.0055)\end{array}$ \\
\hline female & $\begin{array}{r}0.2302 * * * \\
\quad(0.0407)\end{array}$ & $\begin{array}{r}0.2305 * * * \\
(0.0411)\end{array}$ & $\begin{array}{r}0.1070 * * * \\
(0.0257)\end{array}$ & $\begin{array}{r}0.1089 * * * \\
(0.0255)\end{array}$ \\
\hline age & $\begin{array}{r}0.0149 * \\
(0.0078)\end{array}$ & $\begin{array}{r}0.0154 * * \\
(0.0077)\end{array}$ & $\begin{array}{r}0.0097 * * \\
(0.0042)\end{array}$ & $\begin{array}{r}0.0108 * * \\
(0.0043)\end{array}$ \\
\hline age square & $\begin{array}{r}-0.0002^{* * *} * \\
(0.0001)\end{array}$ & $\begin{array}{r}-0.0002^{* * * *} \\
(0.0001)\end{array}$ & $\begin{array}{r}-0.0001 * * * \\
(0.0000)\end{array}$ & $\begin{array}{r}-0.0001 * * * \\
(0.0000)\end{array}$ \\
\hline $\begin{array}{l}\text { vocational } \\
\text { training }\end{array}$ & $0.1332 * * *$ & $0.1305 * * *$ & $0.1028 * * *$ & $0.1045 * * *$ \\
\hline & $(0.0443)$ & $(0.0450)$ & $(0.0210)$ & $(0.0207)$ \\
\hline $\begin{array}{l}\text { university } \\
\text { education }\end{array}$ & $0.1209 * * *$ & $0.1174 * * *$ & $0.0778 * * *$ & $0.0765 * * *$ \\
\hline & $(0.0357)$ & $(0.0360)$ & $(0.0229)$ & $(0.0233)$ \\
\hline married & $\begin{array}{r}0.0363 \\
(0.0480)\end{array}$ & $\begin{array}{r}0.0366 \\
(0.0479)\end{array}$ & $\begin{array}{r}0.0078 \\
(0.0223)\end{array}$ & $\begin{array}{r}0.0060 \\
(0.0204)\end{array}$ \\
\hline municipality size & $\begin{array}{r}-0.0068 \\
(0.0074)\end{array}$ & $\begin{array}{r}-0.0076 \\
(0.0074)\end{array}$ & $\begin{array}{r}-0.0065 \\
(0.0061)\end{array}$ & $\begin{array}{r}-0.0058 \\
(0.0066)\end{array}$ \\
\hline employed & $\begin{array}{r}-0.0519 \\
(0.0665)\end{array}$ & $\begin{array}{r}-0.0529 \\
(0.0662)\end{array}$ & $\begin{array}{r}-0.0420 \\
(0.0309)\end{array}$ & $\begin{array}{r}-0.0391 \\
(0.0323)\end{array}$ \\
\hline retired & $\begin{array}{r}0.0056 \\
(0.0843)\end{array}$ & $\begin{array}{r}0.0044 \\
(0.0837)\end{array}$ & $\begin{array}{r}0.0103 \\
(0.0482)\end{array}$ & $\begin{array}{r}0.0169 \\
(0.0487)\end{array}$ \\
\hline unemployed & $\begin{array}{r}-0.0641 \\
(0.0618)\end{array}$ & $\begin{array}{r}-0.0668 \\
(0.0602)\end{array}$ & $\begin{array}{r}-0.0517 \\
(0.0318)\end{array}$ & $\begin{array}{r}-0.0490 \\
(0.0319)\end{array}$ \\
\hline economic situation & $\begin{array}{r}0.0663 * * * \\
(0.0172)\end{array}$ & $\begin{array}{r}0.0652 * * * \\
(0.0168)\end{array}$ & $\begin{array}{r}0.0323 * * * \\
(0.0096)\end{array}$ & $\begin{array}{r}0.0319 * * * \\
\quad(0.0090)\end{array}$ \\
\hline high class & $\begin{array}{r}0.0238 \\
(0.0774)\end{array}$ & $\begin{array}{r}0.0262 \\
(0.0775)\end{array}$ & $\begin{array}{r}0.0145 \\
(0.0434)\end{array}$ & $\begin{array}{r}0.0145 \\
(0.0437)\end{array}$ \\
\hline medium-high class & $\begin{array}{r}-0.0723 \\
(0.0451)\end{array}$ & $\begin{array}{r}-0.0720 \\
(0.0457)\end{array}$ & $\begin{array}{r}-0.0304 \\
(0.0248)\end{array}$ & $\begin{array}{r}-0.0321 \\
(0.0250)\end{array}$ \\
\hline medium class & $\begin{array}{r}-0.0067 \\
(0.0488)\end{array}$ & $\begin{array}{r}-0.0104 \\
(0.0494)\end{array}$ & $\begin{array}{r}0.0024 \\
(0.0268)\end{array}$ & $\begin{array}{r}0.0005 \\
(0.0267)\end{array}$ \\
\hline political ideology & $\begin{array}{r}-0.0274 * * * \\
(0.0067) \\
\end{array}$ & $\begin{array}{r}-0.0275 * * * \\
(0.0067) \\
\end{array}$ & $\begin{array}{r}-0.0168 * * * \\
(0.0047)\end{array}$ & $\begin{array}{r}-0.0170 * * * \\
(0.0047)\end{array}$ \\
\hline
\end{tabular}


Table Al (cont'd). Coefficient estimates from robustness checks regressions.

\begin{tabular}{lrrrr}
\hline \hline $\begin{array}{l}\text { Dependent } \\
\text { variable: } \\
\text { lockdown support }\end{array}$ & $\begin{array}{r}\text { Ordered } \\
\text { Probit }\end{array}$ & $\begin{array}{r}\text { (2) } \\
\text { Ordered } \\
\text { Probit }\end{array}$ & $\begin{array}{r}\text { (3) } \\
\text { OLS }\end{array}$ & $\begin{array}{r}\mathbf{( 4 )} \\
\text { OLS }\end{array}$ \\
\hline catholic & -0.0300 & -0.0297 & 0.0036 & 0.0034 \\
& $(0.0473)$ & $(0.0482)$ & $(0.0332)$ & $(0.0335)$ \\
trend & $-0.0178^{*}$ & -0.0135 & $-0.0100^{* * *}$ & 0.0031 \\
& $(0.0094)$ & $(0.0116)$ & $(0.0034)$ & $(0.0047)$ \\
Constant & & & $3.4479^{* * *}$ & $3.2616^{* * *}$ \\
& & & $(0.1264)$ & $(0.1488)$ \\
Threshold 1 & -0.3302 & -0.2607 & & \\
& $(0.2023)$ & $(0.1886)$ & & \\
Threshold 2 & 0.2759 & $0.3442^{*}$ & & \\
& $(0.1990)$ & $(0.1873)$ & & \\
Threshold 3 & 0.3220 & $0.3903^{* *}$ & & \\
& $(0.1990)$ & $(0.1870)$ & & \\
Threshold 4 & $3.4093^{* * *}$ & $1.9897^{* * *}$ & & \\
& $(0.1062)$ & $(0.1907)$ & & \\
Province FE & YES & YES & YES & YES \\
\hline Observations & 6,242 & 6,242 & 4,631 & 4,631 \\
Pseudo R-squared & 0.0808 & 0.0803 & & \\
R-squared & & & 0.1090 & 0.1124 \\
\hline \hline
\end{tabular}

Notes: Clustered standard errors at the Autonomous Community level in parentheses. $* * * \mathrm{p}<0.01, * * \mathrm{p}<0.05, * \mathrm{p}<0.1$. 